\title{
آثار الرشاقة في سلسلة الامداد لثبكة التوزيع في سوق السيارات في الملكة العربية السعودية العية (دراسة حالة لوكلاء السيارات)
}

\author{
عبد العزيز صالح العقيل \\ بكالريوس الهندسة الكهربائية ـ ماجستيل العزيل (MSc) سلسلة الإمداد الدولية \\ كلية الهندسة و الرياضيات والعلوم الفيزيائية ـ جامعة إكستر
}

لقد عرف الباحثون الرشاقة في الأعمال (Agility) بأنها السرعة و التكييف مع ما يطلبه العميل، و بأنها واحدة من الأدوات الأساسية التي تحتاجها الثركات في شبكات سلسلة الإمداد الخاصة بها للحفاظ على ميزة تنافسية في بيئة الأعمال الحديثة. تشغل الرشاقة منصبًا رئيسًا في صناعة السيارات. و على الرغم من أهميتها، هناك أدلة

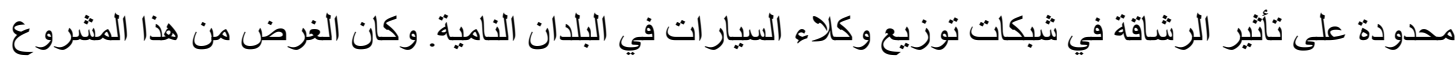
البحثي هو تحديد آثار تحقيق سلاسل التوريد الرشيقة في شبكات التوزيع الخاصة بوكلاء السيارات في المملكة العربية السعودية. تم أخذ عينات من 37 من مديري سلسلة الإمداد و الخبر اء في ثلاثة من أكبر وكلاء السيار ات في المملكة العربية السعودية للار اسة . تم تحليل البيانات الناتجة عن مقياس Likert باستخدام أساليب كرونباخ لمصداقيتها، و الفرضيات تم اختبار ها باستخدام طريقة Chi-Square للبيانات الترتيبية. ووجد البحث أن الرشاقة تزيد من السرعة التي يقوم بها تجار السيار ات بتسليم المنتجات للعملاء وتعزز المعدل الذي يستجييون به لمتطلبات العملاء والسوق المتغيرة. وتبين النتائج أيضا أن الرشاقة في سلاسل الإمداد لا ترتبط بالضرورة ارتباطاً مبانشرًا بمستوى رضا العملاء و انخفاض

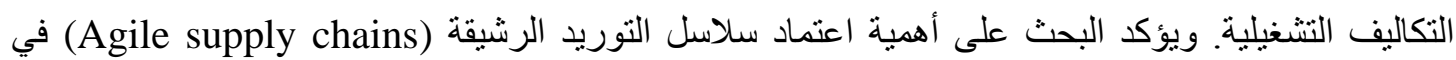
شبكات توزيع تجار السيار ات في المملكة العربية السعودية كوسيلة لزيادة سرعة تقديم الخدمات والقدرة على التكيف مع متطلبات العملاء و التسويق المتغيرة.

الكلمات المفتاحية: سلاسل الإمداد الرشيقة، شبكات توزيع السيارات، السرعة، التكاليف التشغيلية، المرونة، المملكة العربية السعودية. 


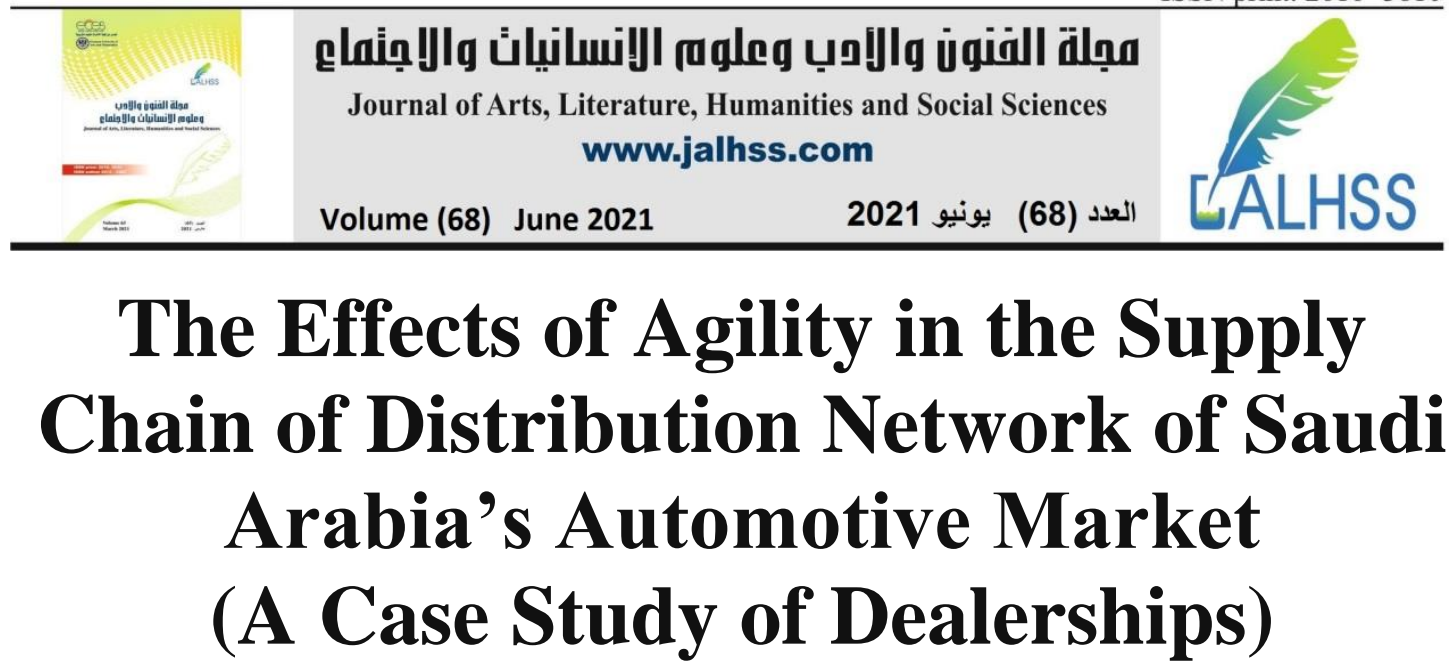

\author{
Abdulaziz Alageel \\ BEng Electrical Engineering - MSc International supply chain \\ College of Engineering, Mathematics and Physical Sciences \\ University of Exeter
}

\begin{abstract}
Researchers have defined agility as one of the fundamental tools companies need in their supply chain networks to maintain a competitive advantage in the modern-day business environment. Agility holds a key position in the automotive industry. Despite its importance, there is limited evidence about the impact of agility in the distribution networks of auto dealerships in developing countries. The purpose of this research project was to identify the effects of achieving agile supply chains in the distribution networks of Saudi Arabia's auto dealerships. 37 supply chain managers and experts in three largest auto dealerships in Saudi Arabia were sampled for the study and five-point Likert Scale questionnaires administered for each one of them. The resulting Likert data was analyzed for reliability using Cronbach's methods and hypotheses tested using Chi-Square method for ordinal data. The research found that agility increases the speed at which auto dealers deliver products to customers and promotes the rate at which they respond to changing customer and market demands. The results also show that agility in supply chains do not necessarily directly linked to the level of customer satisfaction and reduced operational costs. The research confirms the importance of adopting agile supply chains in the distribution networks of auto dealers in Saudi Arabia as a way of increasing the speed of service delivery and adaptability to changing customer and marketing demands.
\end{abstract}

Keywords: Agile supply chains, automotive distribution networks, speed, operational costs, flexibility, Saudi Arabia. 


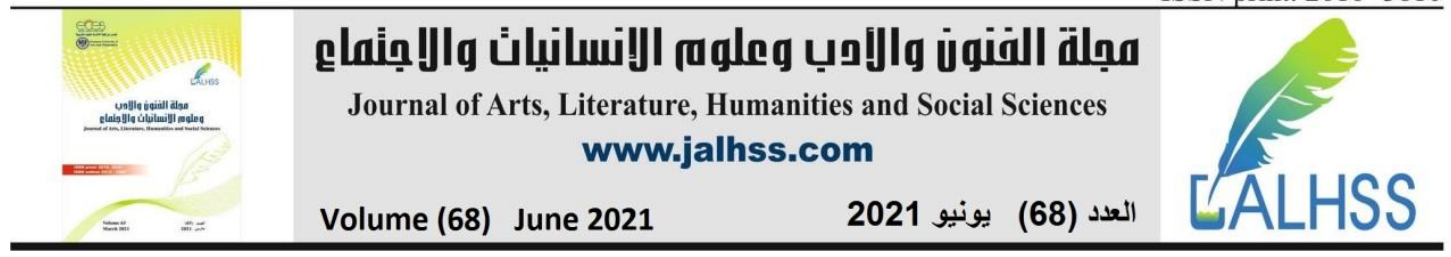

\section{Introduction}

For the past few years, supply chain management (SCM) in the distribution networks of automotive markets has undergone numerous changes. These changes are mainly precipitated by the emergence and advancement of new technologies and innovative developments and increasing rate of competition (Khastoo \& Raad, 2017). One of the vital phenomena that underscore the changes in supply chain management in the automotive sector is agility. Success in the manufacturing and distribution components of various industries depend on the capability of the key players in the industry to engender new ideas, introduce new products, distribute them efficiently to the targeted markets and show high affinity for innovation (Um, 2017). Also, global competition has resulted in a market where it is difficult to achieve growth without adopting flexible and agile techniques during manufacturing and distribution. To survive in today's continually changing business environment, the supply chain management of companies in the automotive sector must become agile (Khastoo \& Raad, 2017).

Saudi Arabia's automotive industry has similar characteristics to other industries in developed countries. Like most companies in the industry, a considerable percentage, if not all, of automotive dealerships in Saudi Arabia have not fully taken the necessary steps to promote and develop agile supply chains in their distribution networks (Mohammadlou, Barzamini \& Khazir, 2016). This matter is a huge concern since agility in manufacturing and supply chain form the basis of performance and success of companies in the modern-day market environment. It is, therefore, essential for Saudi Arabia's automotive dealers to first gain an understanding of the potential impacts of achieving an agile supply chain in their distribution networks. Such an understanding will enable them to put high regard on agility in their supply chain distribution networks and develop a mechanism for implementing the fundamental changes to remain competitive and successful.

The objective of this research is to examine the impacts of achieving an agile supply chain in the distribution networks of Saudi Arabia's automotive dealers. The research will use a case study of automotive dealerships in the country to examine how these companies perceive and integrate agility in the supply chain of their distribution networks and the impacts of these initiatives on various aspects of their organizational performance. The research findings will provide more knowledge on the effects of agility on the performance of supply chains of distribution networks for automotive dealerships. It will also provide a framework for gauging the essentiality and importance of achieving an agile supply chain network in the automotive industry.

\subsection{Research Questions}

The following research questions have been established for this research;

$>$ Does agility in supply chains of the distribution networks of Saudi Arabia's automotive dealers increase the speed of delivering products to customers?

$>$ Does agility in supply chains of the distribution networks of Saudi Arabia's automotive dealers increase the level of flexibility in meeting customers' demands? 


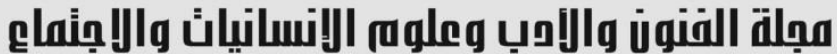 \\ Journal of Arts, Literature, Humanities and Social Sciences www.jalhss.com}

Volume (68) June 2021

2021 يونيو

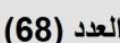

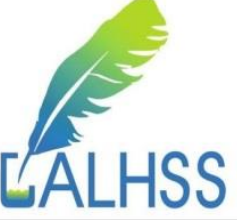

Does agility in supply chains of the distribution networks of Saudi Arabia's automotive dealers increase the level of customer satisfaction?

$>$ Does agility in supply chains of the distribution networks of Saudi Arabia's automotive dealers reduce the overall operational costs?

\subsection{Research Hypotheses}

The following hypotheses were developed for this research

$>$ Agile supply chains increase the speed of delivery of products in the distribution networks of automotive dealerships in Saudi Arabia

$>$ Agile supply chains increase the level of satisfaction of auto dealership customers in Saudi Arabia

$>$ Agile supply chains reduce overall operational costs in Saudi Arabia's auto dealerships

$>$ Agile supply chains increase the level of flexibility of the distribution networks of automotive dealers in Saudi Arabia

\subsection{Research Objectives}

\subsubsection{Main Objective}

The main objective of this research project is to determine the effects of agility in the supply chains of the distribution network of Saudi Arabia's automotive dealers.

\subsubsection{Specific Objectives}

The specific objectives of the research project include the following;

$>$ To determine if agility in the supply chain increases the speed at which automotive dealers in Saudi Arabia deliver services to customers.

$>$ To determine if agility in the supply chain improves the level of customer satisfaction for automotive dealers in Saudi Arabia

$>$ To determine if agile supply chains increase the level of flexibility in the distribution networks of Saudi Arabia's automotive dealers

$>$ To determine if agility in the supply chain reduces the cost of operations in automotive dealerships in Saudi Arabia.

\section{Literature review}

\subsection{The Historical Background of Agility in Supply Chain}

Numerous studies have been conducted on the background of agility and how it came to be an essential concept in supply chain and distribution networks of companies across all industries. The idea of agility in the supply chain began to surface in the late $20^{\text {th }}$ century after being highly popularized by analysts and pundits at the Institute of Lehigh University (Gilgor, 2013). The concept quickly gained traction in terms of applicability and preference by manufacturing firms across the world (Dove, 1994). Automotive giants such as Toyota have adopted the concept of agility in their manufacturing as well as the supply chain of their distribution networks to reduce wastage and ensure optimum movement of products from the manufacturing premises to consumers (Ben et al., 2013). Agility resulted in a profound shift in the way automotive companies around the world addressed changes in global competition. It enabled them to enhance their level of competitiveness in the worldwide market, resulting in business continuity (Gilgor, 2013). 


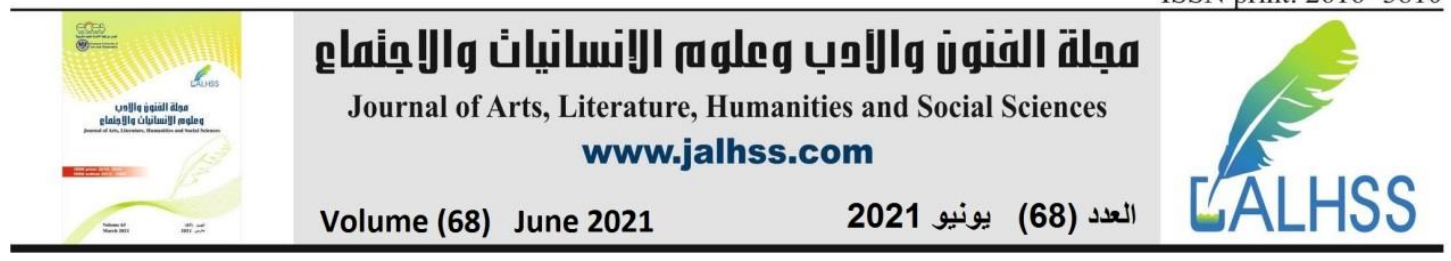

\subsection{The Agile Supply Chain Concept}

The agile supply chain concept was primarily introduced as an application of the most efficient and effective strategies to supply chains (Harrison et al., 1999). In the context of supply chain management, the agile concept focuses on responsiveness, people, and information, and corporation between companies (Ambe, 2009). An agile supply chain is that which portrays the characteristics of market sensitivity, process combination, and networking. However, the concept of agility in the supply chain tends to be multidimensional. This multidimensionality has created confusion and ambiguity in understanding the specific characteristics of agility in the supply chain (Gligo, 2015). It is highly uncommon to see two or more publications adopting the same definition for agility (Conboy, 2009).

The numerous and varied definitions of agility in the supply chain occur as a result of the unique domains in the manufacturing, service, and agricultural sectors. Some of these definitions are beyond the scope of this study. It is thus essential to limit the definitions to focus on the automotive industry. The case for agility in the automotive sector depends on intensified global competition and reduction in the lead-time for product development as well as its life expectancy (Tarokh, Ghahremanloo \& Karami, 2007). The short life cycles of automotive products, as precipitated by rigorous environmental regulations in many countries, requires different manufacturing and supply chain of distribution networks that focus on rapid response, continued innovation, flexibility and good quality at the lowest cost (Tarokh, Ghahremanloo \& Karami, 2007). According to Tarokh and colleagues, this is what entails agility in the supply chain management of distribution networks in the automotive sector. While Tarokh and colleagues focus on global competition and reduction in lead time, $\mathrm{Wu}$ and Angelis (2007) focus on advanced technology and diversification of distribution techniques as fundamental features that describe an agile supply chain in the automotive sector. Tarokh, Ghahremanloo \& Karami (2017) provide a comprehensive definition by stating that agility in the supply chain means the ability of an automotive company to structure its distribution networks in such a way that they can rapidly respond to changes in customer demands both in the form of quantity of products as well variety. The element of agility in the supply chain, as proposed by Tarokh and colleagues, is presented in Fig 2.1 below.

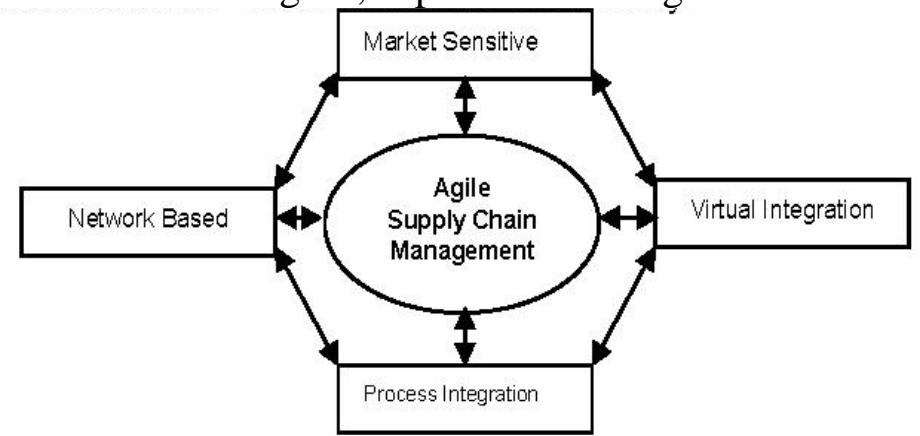

Figure 2.1: Elements of Agile Supply Chain Management (Tarokh, Ghahremanloo \& Karami, 2007) 


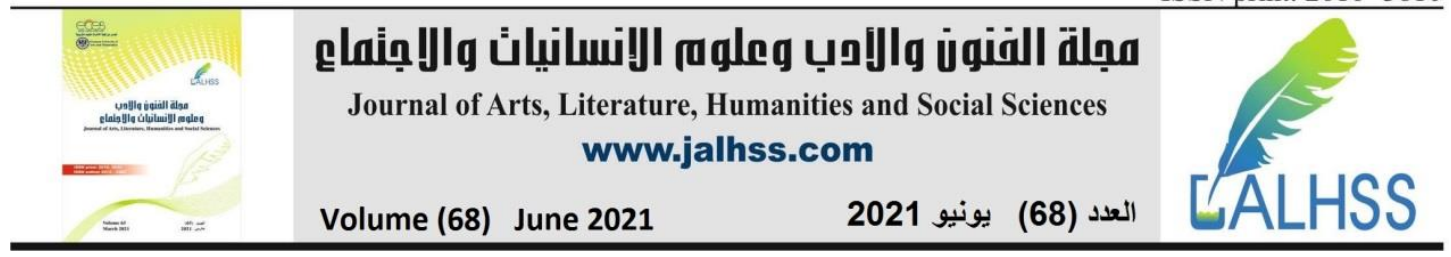

The agile supply chain concept comes with numerous benefits to the automotive dealers that practice it as well as the targeted customers. In their research publication, term agility as a vital tool that enables companies to streamline their manufacturing and distribution processes to remain competitive. Khastoo and Raad (2017), on the other hand, state that agility in the supply chain enables companies to achieve maximum customer satisfaction by responding adequately to their changing needs and preferences in the distribution network. No publication that further supports the connection between an agile supply chain and customer satisfaction. Khastoo and Raad (2017) add that agility enables companies in the automotive sector to collaborate effectively with partners to enable them to respond to market changes. Furthermore, a study conducted by Whitten et al. (2012) shows that agility in the supply chain is a reliable indicator of an organization's success. While many publications appear to portray agility as a concept that comes with more benefits than disadvantages, it is also important to acknowledge past research done to identify the potential weaknesses of agile supply chains. While no publication directly links agile supply chain capabilities to failures in companies, Christopher et al. (2016) explore the trade-offs associated with implementing agile supply chains. They indicate that agile supply chains reduce the need for labour and even encourages employers to lay off people as a response to improved efficiency. Therefore, agile supply chains may be a disadvantage from a humanistic point of view. However, the author acknowledged that agile supply chains improve operational efficiency and overall firm performance.

However, despite the significant benefits associated with agile supply chain networks, Saad and Patel (2006) say that many companies, particularly dealers in the automotive sectors, are yet to achieve agile supply chains. Figure 2.2 below represents the components and structure of a typical supply chain.

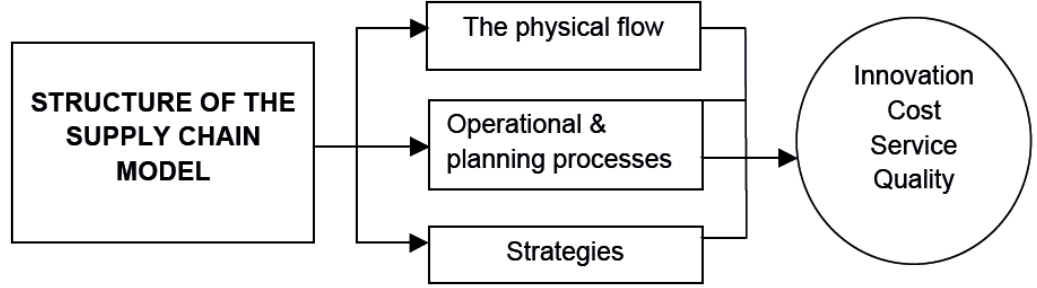

Figure 2.2: Components of the Supply Chain Model (Ambe \& Bardenhorst, 2011)

\subsection{Agility and Speed}

Researchers and industry experts have pondered on the concept of agility and how it impacts the speed of service delivery in the automotive sector as well as other industries. Ambe (2009) examined the link between agility in supply chains and the competitive advantage of companies in the automotive industry. He identified speed as one of the primary elements of competitiveness that improve due to agile supply chains. Organizations that operate in highly volatile and competitive business environments tend to benefit from an increase in speed at which employees process customer orders, solve emerging complaints and deliver the respective orders to their destinations (Ambe, 2009). However, Ambe approaches the concept of speed as a product of agile supply chains using systemic analysis of past literature and metadata 


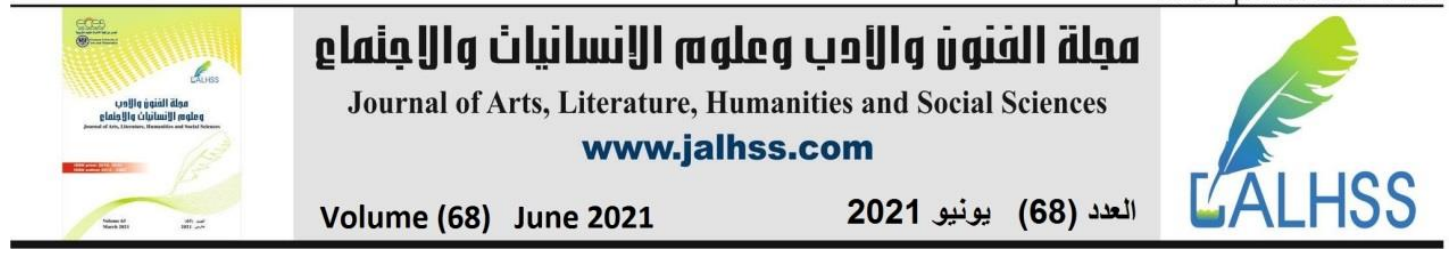

on supply chain management. While systemic analyses may be reliable in scenarios where there is an already established and homogenous perception about the contentious issue, the data generated from such analyses may not be based on evidence applicable to current dynamics and developments in the industry (Mallet et al., 2012). Quantitative and qualitative techniques will bring out more reliable results relevant to current industry trends (Rahman, 2017).

\subsection{Agility and Flexibility}

Apart from speed, researchers and experts have linked agility in supply chains to the flexibility of distribution networks of automotive companies. Others have linked agility in the supply chain to overall operational flexibility. Vickery, Calantone, and Droge (1999) define flexibility as the ability of a company to respond to changing demands of customers and the market. Grigore (2007), on the other hand, defines flexibility as the ability of supply chain distribution networks to vary service packages according to emerging needs with little impact on time, effort, cost or performance. Manders (2010) defines flexibility in the supply chain as the ability of companies to react cost-effectively to the environmental uncertainties to meet customer demands and market changes. Zhang et al. (2002) define flexibility as the ability of companies to meet an increasing variety of expectations from customers without activating negative trade-offs such as reduced firm performance, increased operational costs, and time wastage. The ultimate aim of flexibility in the supply chain is to adapt to existing situations to achieve maximum customer satisfaction (Grigore, 2007). The concept of flexibility in supply chains has three distinct characteristics; responsiveness, variety, and uniformity (Manders, 2010). Other distinct features depend on the internal potentially for flexibility, such as availability of resources to execute a proper response framework to the emerging changes. There is also manifested flexibility, which is a component of what the customer sees (Manders, 2010).

\subsection{Agility and Customer Satisfaction}

Literature links agile supply chains to customer satisfaction. Power, Sohal, and Rahman (2001) categorize customer satisfaction as one of the critical success factors of an agile supply chain in any industry. They say that organizations that adopt agile supply chains tend to be more customer-focused and apply a combination of methodologies to meet changing customer requirements. Customer satisfaction is an important goal of agile supply chains and forms the basis of process strategies meant to enhance the performance of the supply chain of distribution networks (Mohammad Lou et al., 2016). Another study conducted by Barve (2011) confirms the achievement of a higher rate of customer satisfaction as one of the critical positive effects of agile supply chains. Barve conducted a meta-analysis on past research-based evidence and discovered that companies that adopted agile supply chain management strategies were more likely to achieve high rates of customer satisfaction than those that did not. However, customer satisfaction occurs as a result of the immediate impacts of agility. Barve (2011), for instance, portrays customer satisfaction as a resultant effect of improved response time and quality of products that occur due to the existence of agile supply chain networks within organizations. 


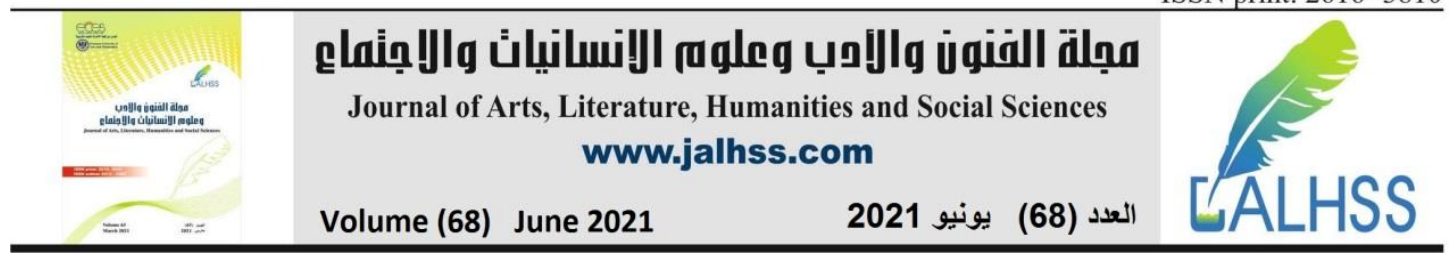

\subsection{Agility and Operational Costs}

A comprehensive literature search conducted for this project did not find any research-based evidence that directly links agile supply chains to reduced operational costs. However, a considerable percentage of literature relates the trade-offs of the agile supply chain to reduced operational costs within companies. Towill and McCullen (1999) examine the impact of agile supply chains on operational and customer dynamics as the possible link between agility and reduced operational costs. They infer that improvement in supply chain performance minimizes production waste, thereby increasing efficiency while lowering the rate of consumption of raw materials and other essential resources. Cluster analysis and validation conducted by Khan et al. (2009) on the impact of agile supply chain practices on firms' performance in the automotive sector also portray similar results. Khan and colleagues found that agile supply chains improved the quality of services delivered, allowed for the integration of more technology and enabled companies to respond efficiently to the emerging customer and market demands with minimal impacts on costs. These elements were associated with a reduction in the demand for labour, increased customer retention, and overall decrease in the cost of production. LaLonde and Pohlen (1996) also link agility to reduced supply chain costs. However, they do not mention how agility impacts overall organizational costs.

\subsection{The Role of Technology}

While many literatures have focused on the positive trade-offs of agile supply chains such as speed, flexibility, customer satisfaction, consciousness, and decisiveness, one element underscores these trade-offs: technology. As mentioned by Al-Sadoum (2017), technology forms the primary basis for actualizing the positive trade-offs of agile supply chains of the distribution networks of Saudi Arabia's automotive dealers. It does not only apply to the internal demands among these dealerships but also to external links between the dealerships to the market, potential clients, and existing ones. Disruptive technologies such as big data analytics, advanced robotics and augmented reality have been found to be critical components of the effective and agile supply chains (Aryal et al., 2018) Aryal and colleagues are simply trying to insinuate that agile supply chains cannot exist without proper integration with technology.

When it comes to the Saudi Arabian's automotive industry, Alhashim (2018) opines that technology has greatly improved transparency, security, and management of the export/import procedures in the country. For instance, custom agents can get automated notifications on their cell phones that inform them of their shipment status and can generate their declarations immediately the shipping manifest is accessible online. Imran and Rizwan (2013) attest that the port community system which the Saudi government had initiated has improved efficiency and security in exchange of information among individuals involved in export/import processes, digital payments, vessel operations, and management of trucks. 


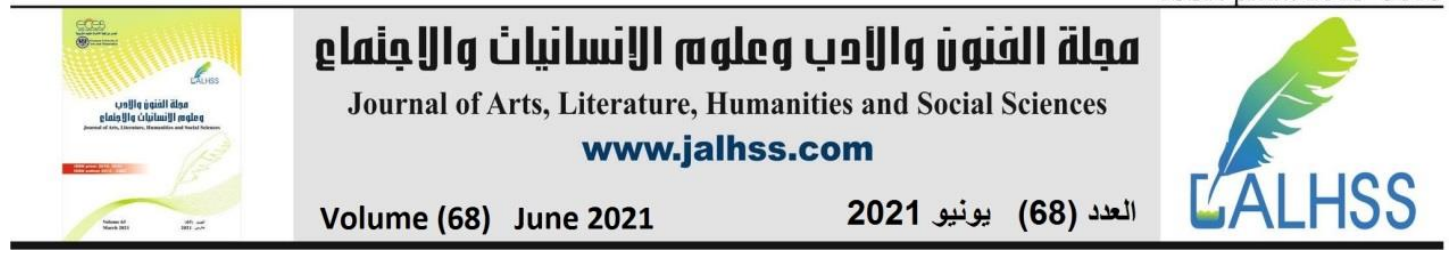

\subsection{The Negative Trade-Offs of Agility}

It is within the scope of this research project to look into the negative tradeoffs of agility in the supply chain of the distribution networks of automotive dealers in Saudi Arabia. As Navid and Ismaili (2012) state, one of the key factors of agile supply chains is automation. They define automation as the replacement of manual techniques in supply chains with computerized methods. This way, operations in the distribution networks can be done with minimal impact on human power. Even though the objective of automation in supply chains is to make them as agile as possible, Ambe (2009) acknowledges that they result in potential trade-offs. The desire to achieve automation at the expense of reducing dependence on labour is a negative trade-off to employees who depend on the manual packaging and processing techniques in the distribution networks. Carbonero et al. (2018) acknowledge that the increasing usage of robotic techniques in supply chain networks will continue to pose a serious threat to the number of people employed in supply chain. Research find robots to have a statistically negative impact on employment, especially for emerging economies like Saudi Arabia. In addition to massive unemployment, Kawa and Maryniak (2019) identify increased costs as another significant undesirable impact of agile supply chains on the automotive sector. Just like Carbonero and colleagues, Kawa and Maryniak tie increased costs to the attempts by supply chain managers to introduce new tools and techniques that allow them to become agile. The desire to use e-commerce as the primary platform for processing orders and tracking customer requests has increased the overall expenses automotive dealers incur in their supply chain budgets. However, Kawa and Maryniak, at the same time, recognize that the positive impact of these initiatives outweighs the negative ones in the long-term.

\subsection{The Current State of Agile Supply Chain in the Automotive Sector}

The automotive industry consists of manufacturers, dealers, and consumers who are intertwined in a supply chain web. The top five players in this industry include Toyota, General Motors, Volkswagen, and Daimler Chrysler (Braese, 2005). These companies have grown as a result of the highly functional supply chain of their distribution networks (Gonzalez et al., 2019). However, the current market dynamics, characterized by changes in technology and consumer preferences have put a considerable amount of pressure on supply chain management networks in the automotive industry (Saranga, Mukherji \& Shah, 2015). Automotive dealers are particularly struggling with the limitations of Build-to-Order, a concept widely adopted by automotive manufacturers to promote maximum satisfaction by responding to changing and varied demands of specific customers (Braese, 2005). This concept has been challenging to implement because companies tend to mix popular and unpopular options, reducing quality in the process.

Since technology plays an integral role in maximizing the potential of supply chain distribution networks in the automotive sector, this literature review deemed it essential to look into how automotive dealers in Saudi Arabia have integrated technology in their distribution networks. A report published by DHL, a leading global logistics company, shows that automotive dealers in Saudi Arabia are turning to new data analytics tools and strategies to eliminate poor performance in their 


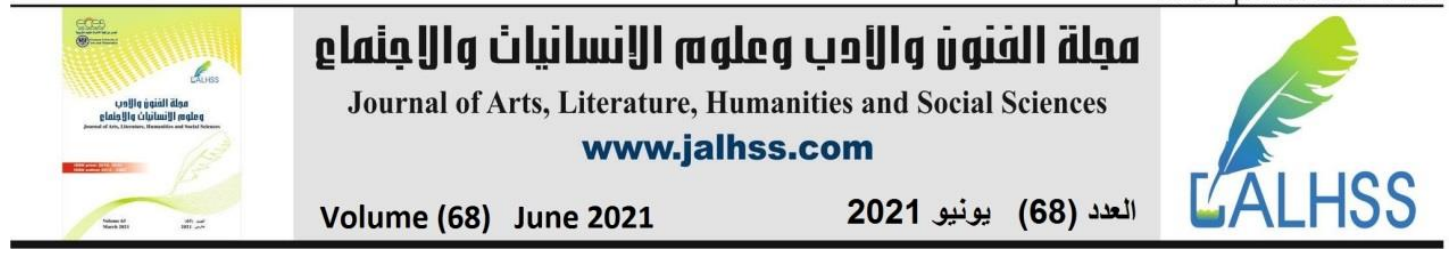

supply chain distribution networks. Many of the companies mentioned attributed the use of data analytics in their agile supply chain distribution networks to improved performance of the supply chain staff and overall customer satisfaction. The increased customer satisfaction has already brought a positive impact on the companies that have implemented them and the industry at large. DHL mentions that industry growth directly attributed to the integration of technology in agile supply chains is going to be immense. It estimates company sales to expand at around $2.7 \%$ with more than 89 million units sold in the coming years. Even though the DHL's report shows the close link between technology and the effectiveness of agile supply chain techniques, it does not directly attribute technology as a factor contributing to improved flexibility, customer satisfaction and speed of service delivery among automotive dealers in Saudi Arabia.

\subsection{Automotive Dealerships in Saudi Arabia; A Case Study}

Saudi Arabia is considered one of the top markets for car manufacturers around the world. The country imports more than one million cars per year and offers a lucrative potential for automotive manufacturers (Randheer et al., 2017). The Saudi Arabian government has put in place various measures such as tax incentives, lower tariffs, improved security, and adequate infrastructure to attract potential automotive investors in the country (Randheer et al., 2017). These steps are part of the government's ambition to revamp the manufacturing sector, as highlighted in Vision 2030. The recent law that allows women to drive in Saudi Arabia has also seen a surge in demand for cars (See Figure 2.3 below). Due to the positive business environment, automotive dealers in the country have seen an increase in activities in recent years (Tausif \& Haque, 2018). The increased level of activities in the Saudi Arabian automotive sector has put a considerable level of pressure on the critical functional areas of automotive dealerships (Tausif \& Haque, 2018). The increasing number of vehicles that enter the country through the ports and the re-energized focus by top automotive manufacturers such as Toyota, Ford and Chrysler mean the distribution networks of automotive dealers will be more busy than usual. As Tausif and Hague (2018) mention, an increase the demand for cars results into a considerable need for the supply chains of distribution networks to put into place various measures that ensure utmost effectiveness of their supply chain. Such measures will require the concerned supply chains to develop agile capabilities.

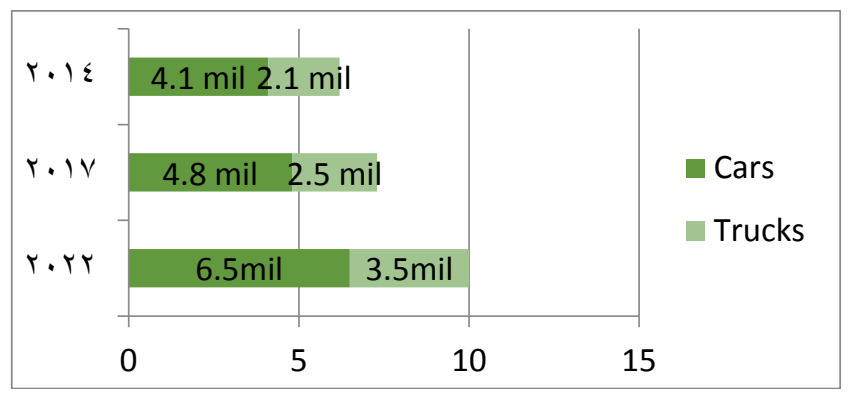

Figure 2.1: Saudi Arabia Car and Truck Imports (CAGR, 2019) 


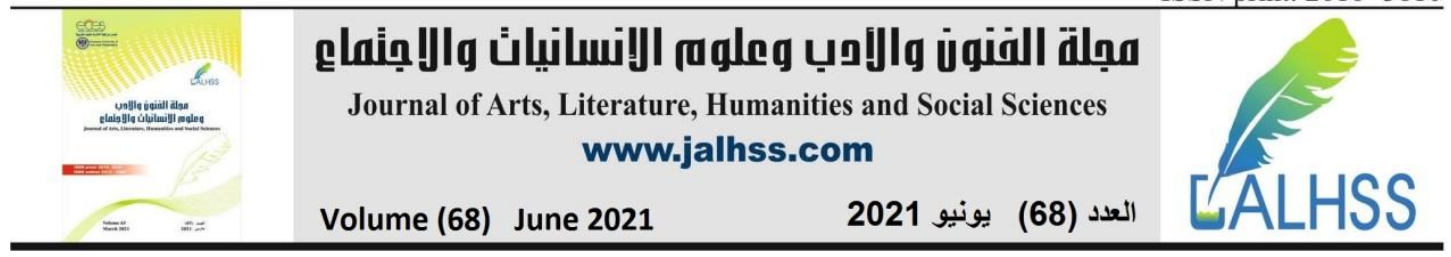

Automotive dealerships in Saudi Arabia use traditional supply chain systems that do not contain the four agile capabilities. In these systems, marketing and sales take a best guess at the dynamics influencing market demand and then use forecasts made to design SCM teams that determine model production volumes (Howard, Miemcyzk \& Graves, 2006). The companies focus on achieving lean processes and supporting technologies. Due to the high cost of re-engineering and supporting technologies, many companies opt to use normal practices in the SCM and distribution networks and have little room for promoting flexible and evolutionary practices (Ambe \& Badenhorst, 2011). However, indicates that companies have leveraged the internet to redefine their processes and meet their customer needs, which is a good thing for SCM and distribution networks. However, Stevenson fails to mention how the internet integrates exactly to SCM and distribution network and how it promotes agility.

\subsection{Examining Saudi Arabia's Automotive Distribution Network}

The Saudi government is keen on improving its transport and distribution network as evident through its 2018 budget that includes an increase of about $86 \%$ on transportation and infrastructure (Saudi Arabia Country Commercial Guide, 2018). Additionally, the country is planning on improving its railway freight capacity through additional funding, which will also be used to improve the rail network. The Ministry of Transport has received funding from the government to ease the operations at the port (Taylor \& Demirbas, 2016). Dealerships in Saudi Arabia use a conventional distribution network in their distribution chains. A traditional network of distribution follows what Chopra (2003) calls a distributor storage with carrier delivery framework. In this option, manufactures do not hold the vehicles produced at their factory premises but rather at the dealerships where they are transported using package carriers to the final customer (Chopra, 2003). This distribution network is highlighted in Figure 2.4.

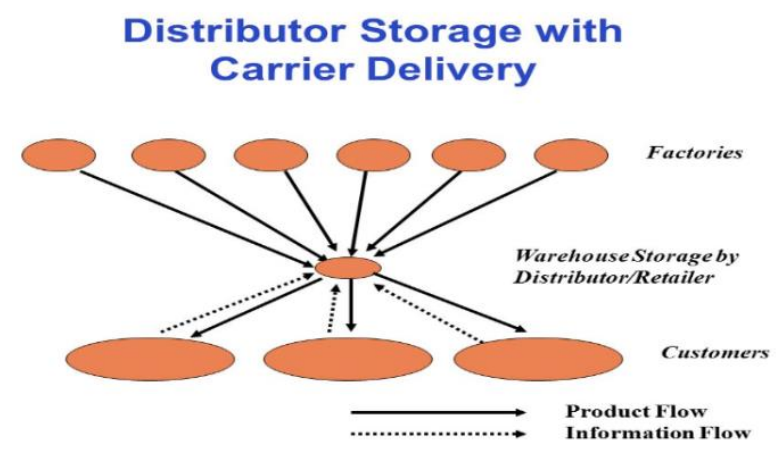

Figure 2.4: A Typical Distribution Network in Saudi Arabia's Automotive Industry (Chopra, 2003)

\section{Research methods}

The research design is intended to develop a connection between the research questions and hypotheses with the detailed methods for data collection, analysis, and interpretation (Creswell, 2009). The research plan is designed to obtain crucial answers to the research questions of interests to the dissertation. The chapter will 


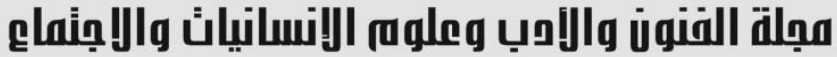 \\ Volume (68) June 2021 \\ العدد (68) يونيو 2021}

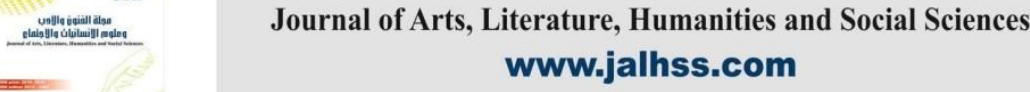

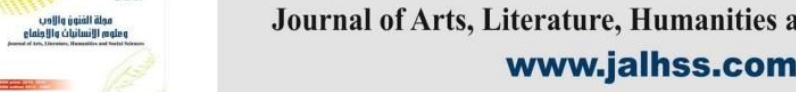

cover the procedures taken to select the participants, the design and administration of questionnaires, ethical considerations, research assumptions, the industrial sector studied, the reliability tests, and the frequency tests. The data collection methodology employs a quantitative research design using surveys administered in the form of Liker Scale questionnaires.

\subsection{Sector Studied}

This study targeted the three largest automobile dealers that have been shown to use agile supply chain techniques in Saudi Arabia. The dealerships have been in business for the last thirty years and command some of the most efficient operational systems in the whole of Saudi Arabia. These dealers adopted the five capabilities of agile supply techniques in their operational model. These concepts include access, decisiveness, flexibility, speed, and consciousness. The dealers have wide distribution networks spread across major towns in Saudi Arabia. The dealers also specialize in a wide range of vehicles, specifically made for specific target markets. These dealers have fully developed supply chain management infrastructure with a team of experienced and knowledgeable employees on agile techniques.

\subsection{Participants}

Research participants were exclusively drawn from the three car dealerships in Saudi Arabia. The decision to select the three dealerships for this research was inspired by trong indications that the companies had developed agile supply chain networks. These indications were given by academic and industry experts in supply chain management in Saudi Arabia. The participants included in the study consisted of both supply chain managers and employees. Only employees who worked with special teams that designed and implemented agile supply chain strategies in these dealerships were selected. This criterion was used because supply chain managers and employees who work in special teams meant to implement agile techniques have a better understanding of the impacts of these techniques. They are able to track them using the key performance indicators (KPIs) developed before the implementation of these techniques. Every respondent had a minimum level of experience of five years in supply chain and distribution management. This level of experience was important for this study because it ensured that only employees who are highly knowledgeable about their organizations' supply chains and distribution networks were eligible to respond. Experienced and knowledgeable respondents increase the reliability and credibility of research by a margin of up to $10 \%$ (Kawulich, 2005).

\begin{tabular}{|l|l|}
\hline Dealership & Response Rate $(\%)$ \\
\hline $1^{\text {st }}$ Dealership & 100 \\
\hline $2^{\text {nd }}$ Dealership & 86 \\
\hline $3^{\text {rd }}$ Dealership & 79 \\
\hline
\end{tabular}




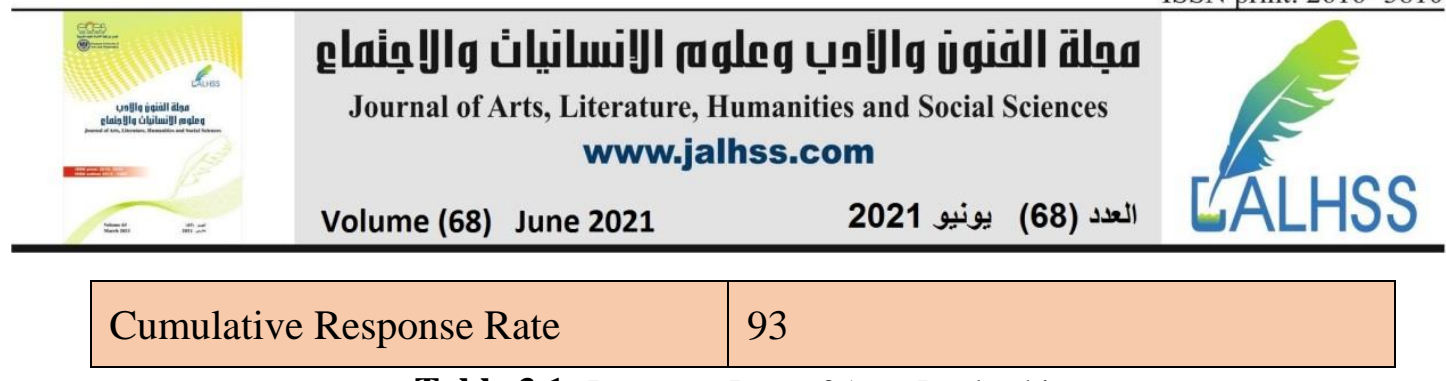

Table 3.1: Response Rate of Auto Dealerships

\subsection{Survey Pre-Test}

The Likert items were subjected to survey pre-test to increase reliability and decrease measurement error of the final survey results. The test focused on refining the contents of the questionnaires to make sure they presented an accurate picture of the agile supply chain networks in Saudi Arabia's automotive industry. To conduct the pre-test, personalized emails were sent to the deans of schools of business at two Saudi Universities to provide academic and expert opinion on the relevance of the questions to Saudi Arabia's automotive industry. The questionnaires were also sent 11 more industry experts. The experts were selected depending on their research interests and industry experience. The experts were asked to evaluate each of the Likert items based on validity and provide quantitative feedback. 12 out of 13 responded, which represented $92 \%$ response rate. The respondents confirmed all the survey questions for validity (See Table 3.2 below).

\begin{tabular}{|l|l|l|l|}
\hline \multicolumn{1}{|c|}{ Likert Item } & $\begin{array}{c}\text { Strongly } \\
\text { Agree }\end{array}$ & Neutral & $\begin{array}{l}\text { Strongly } \\
\text { Disagree }\end{array}$ \\
\hline $\begin{array}{l}\text { The agile supply chain has increased the speed at } \\
\text { which ordered cars reach customers in your } \\
\text { organization. }\end{array}$ & 10 & 1 & 1 \\
\hline $\begin{array}{l}\text { The agile supply chain has improved the level of } \\
\text { satisfaction of your customers from the feedback } \\
\text { you get. }\end{array}$ & 8 & 1 & 3 \\
\hline $\begin{array}{l}\text { Is your organization now flexible in dealing with } \\
\text { unexpected demands since it adopted an agile } \\
\text { supply chain? }\end{array}$ & 11 & 0 & 1 \\
\hline Agility has reduced operational costs. & 8 & 2 & 2 \\
\hline
\end{tabular}

Table 3.2: Expert Response Based on Validity of the Likert Items

\subsection{Data Analysis}

The analysis of the Likert Scale data was performed using Excel spreadsheets and SPSS. The excel spreadsheets were used to analyse the percentage frequencies of each dependent variable (speed, flexibility, operational costs, and customer satisfaction). 


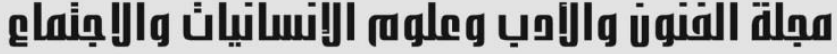 \\ Journal of Arts, Literature, Humanities and Social Sciences www.jalhss.com \\ Volume (68) June 2021 \\ العدد (68) يونيو 2021}

\section{Results}

\subsection{Reliability Tests}

The Cronbach's Alpha value for the Likert data set was 0.723 (See figure below). The value was more than $0.7(\alpha>0.7)$. Therefore, there was an acceptable degree of consistency in the questionnaires. The number of items tested against the Cronbach's Alpha was 4. The Cronbach's Alpha on standardized items was 0.690.

Case Processing Summary
\begin{tabular}{ll|r|r} 
& \multicolumn{1}{c}{ N } & \multicolumn{1}{c}{$\%$} \\
\hline \multirow{2}{*}{ Cases } & Valid & 37 & 100.0 \\
\cline { 2 - 4 } & Excluded $^{\text {a }}$ & 0 & .0 \\
\cline { 2 - 4 } & Total & 37 & 100.0 \\
\hline
\end{tabular}

a. Listwise deletion based on all variables in the procedure.

\subsection{Hypothesis Testing}

The following hypotheses were tested

1. Agile supply chains increase the speed of delivery of products in the distribution networks of automotive dealerships in Saudi Arabia

2. Agile supply chains increase the level of satisfaction of auto dealership customers in Saudi Arabia

3. Agile supply chains increase the level of flexibility of the distribution networks of automotive dealers in Saudi Arabia

4. Agile supply chains reduce overall operational costs in Saudi Arabia's auto dealerships.

Hypothesis 1: Agile supply chains increase the speed of delivery of products in the distribution networks of automotive dealerships in Saudi Arabia of products.

Null hypothesis $\mathrm{H}_{0}=$ Agile supply chains do not increase the speed of delivery

\section{Speed}

\begin{tabular}{lr}
\multicolumn{2}{|c}{ One-Sample Chi-Square Test Summary } \\
\hline Total N & 37 \\
\hline Test Statistic & $17.595^{\mathrm{a}}$ \\
\hline Degree Of Freedom & 3 \\
\hline $\begin{array}{l}\text { Asymptotic Sig.(2-sided } \\
\text { test) }\end{array}$ & .001 \\
\hline
\end{tabular}

Figure 4.2: P-Value for Hypothesis 1

The $\mathrm{p}$-value for the first hypothesis was 0.001 . The $\mathrm{p}$-value was less than 0.05 (p-value< 0.05). Therefore, the null hypothesis was rejected. This meant that the 


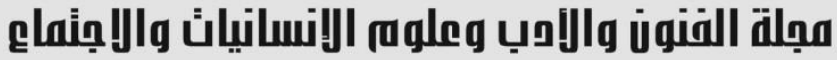 \\ Journal of Arts, Literature, Humanities and Social Sciences www.jalhss.com \\ Volume (68) June 2021 \\ العدد (68) يونيو 2021

sample selected highly represent the probability that agility increase the speed of delivery of products across the distribution networks of all auto dealers in Saudi Arabia.

Hypothesis 2: Agile supply chains increase the level of satisfaction of auto dealership customers in Saudi Arabia

Null Hypothesis $\mathrm{H}_{0}=$ Agile supply chains do not increase the level of satisfaction of auto dealership customers in Saudi Arabia.

\section{Satisfaction}

\section{One-Sample Chi-Square Test Summary}

\begin{tabular}{lr}
\hline Total N & 37 \\
\hline Test Statistic & $3.405^{\mathrm{a}}$ \\
\hline Degree Of Freedom & 4 \\
\hline $\begin{array}{l}\text { Asymptotic Sig.(2-sided } \\
\text { test) }\end{array}$ & .492 \\
\hline
\end{tabular}

Figure 4.3: P-Value for Hypothesis 2

The $\mathrm{p}$-value for the second hypothesis was 0.492 . The $\mathrm{p}$-value was greater than 0.05 ( $>>0.05)$. Therefore, the null hypothesis was retained. This meant that the sample selected did not represent the probability that agility in supply chains increased the rate of satisfaction of automotive customers in Saudi Arabia.

Hypothesis 3: Agile supply chains increase the level of flexibility of the distribution networks of automotive dealers in Saudi Arabia

Null Hypothesis $\mathrm{H}_{0}=$ Agile supply chains do not increase the level of flexibility of the distribution networks of automotive dealers in Saudi Arabia.

\section{Flexibility}

\section{One-Sample Chi-Square Test Summary}

\begin{tabular}{lr}
\hline Total N & 37 \\
\hline Test Statistic & $22.865^{\mathrm{a}}$ \\
\hline Degree Of Freedom & 4 \\
\hline $\begin{array}{l}\text { Asymptotic Sig.(2-sided } \\
\text { test) }\end{array}$ & .000 \\
\hline
\end{tabular}

Figure 4.4: P-Value for Hypothesis 3

The $\mathrm{p}$-value for the third hypothesis was 0.000 . The $\mathrm{p}$-value was less than 0.05 $(\mathrm{p}<0.05)$. Therefore, the null hypothesis was retained. This meant that the sample selected did not represent the probability that agility in supply chains increased the rate of satisfaction of automotive customers in Saudi Arabia.

Hypothesis 4: Agile supply chains reduce overall operational costs in Saudi Arabia's auto dealerships 


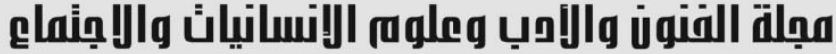 \\ Journal of Arts, Literature, Humanities and Social Sciences www.jalhss.com \\ Volume (68) June 2021 \\ العدد (68) يونيو 2021}

Null Hypothesis $\mathrm{h}_{0}=$ Agile supply chains do not reduce overall operational costs in Saudi Arabia's auto dealerships

\section{Costs}

\begin{tabular}{l}
\multicolumn{2}{|c|}{ One-Sample Chi-Square Test Summary } \\
\begin{tabular}{|lr} 
Total N & 37 \\
\hline Test Statistic & $3.946^{\text {a }}$ \\
\hline Degree Of Freedom & 4 \\
\hline $\begin{array}{l}\text { Asymptotic Sig.(2-sided } \\
\text { test) }\end{array}$ & .413 \\
\hline
\end{tabular} \\
\hline
\end{tabular}

Figure 4.5: P-Value for Hypothesis 4

The $\mathrm{p}$-value for the second hypothesis was 0.413 . The $\mathrm{p}$-value was greater than 0.05 ( $>0.05$ ). Therefore, the null hypothesis was retained. This meant that the sample selected did not represent the probability that agility in supply chains reduced the overall operational costs increased the rate of satisfaction of automotive customers in Saudi Arabia.

\subsection{Frequency Tests}

The results of the frequency tests are highlighted below;

Table 4.3: Percentage Score of Dependent Variables

\begin{tabular}{|l|l|l|l|l|l|l|}
\hline & $\begin{array}{c}\text { Strongly } \\
\text { Agree }\end{array}$ & Agree & Neutral & Disagree & $\begin{array}{c}\text { Strongly } \\
\text { Disagree }\end{array}$ & Total \\
\hline Increased Speed & $22 \%$ & $54 \%$ & $14 \%$ & $11 \%$ & $0 \%$ & $100 \%$ \\
\hline $\begin{array}{l}\text { Improved Customer } \\
\text { Satisfaction }\end{array}$ & $11 \%$ & $19 \%$ & $22 \%$ & $30 \%$ & $19 \%$ & $100 \%$ \\
\hline Increased Flexibility & $46 \%$ & $30 \%$ & $11 \%$ & $11 \%$ & $3 \%$ & $100 \%$ \\
\hline $\begin{array}{l}\text { Reduced Operational } \\
\text { Costs }\end{array}$ & $8 \%$ & $27 \%$ & $22 \%$ & $24 \%$ & $19 \%$ & $100 \%$ \\
\hline
\end{tabular}

\subsubsection{Increased Speed}

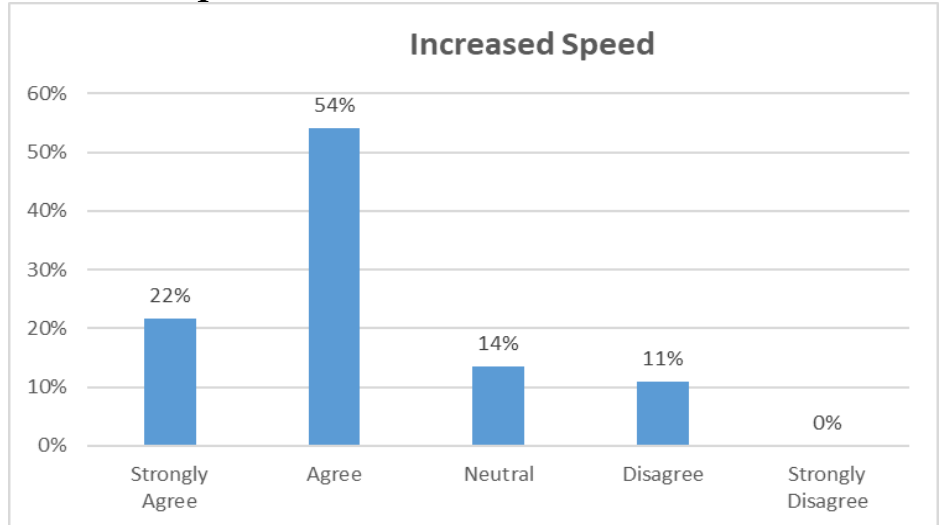




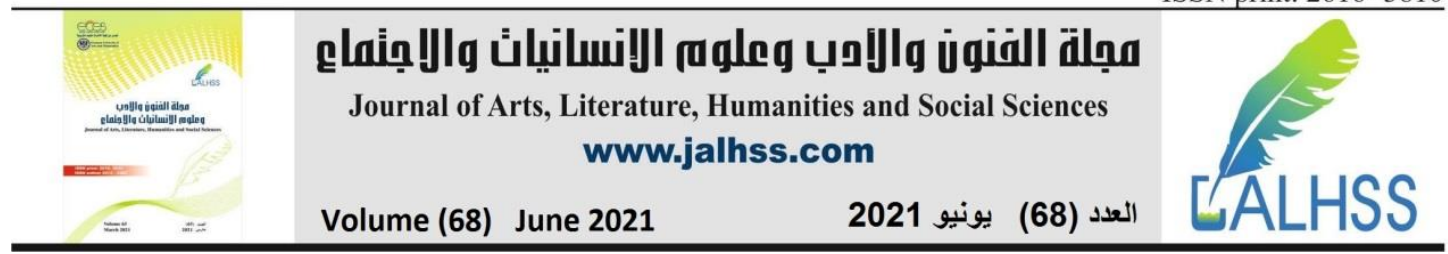

Figure 4.6: Response on Increased Speed

$54 \%$ of the respondents agreed that agility increased the speed at which products reach customers in the supply chain of the distribution networks of automotive dealers in Saudi Arabia. 22\% strongly agreed while 11\% disagreed. None of the respondents strongly disagreed.

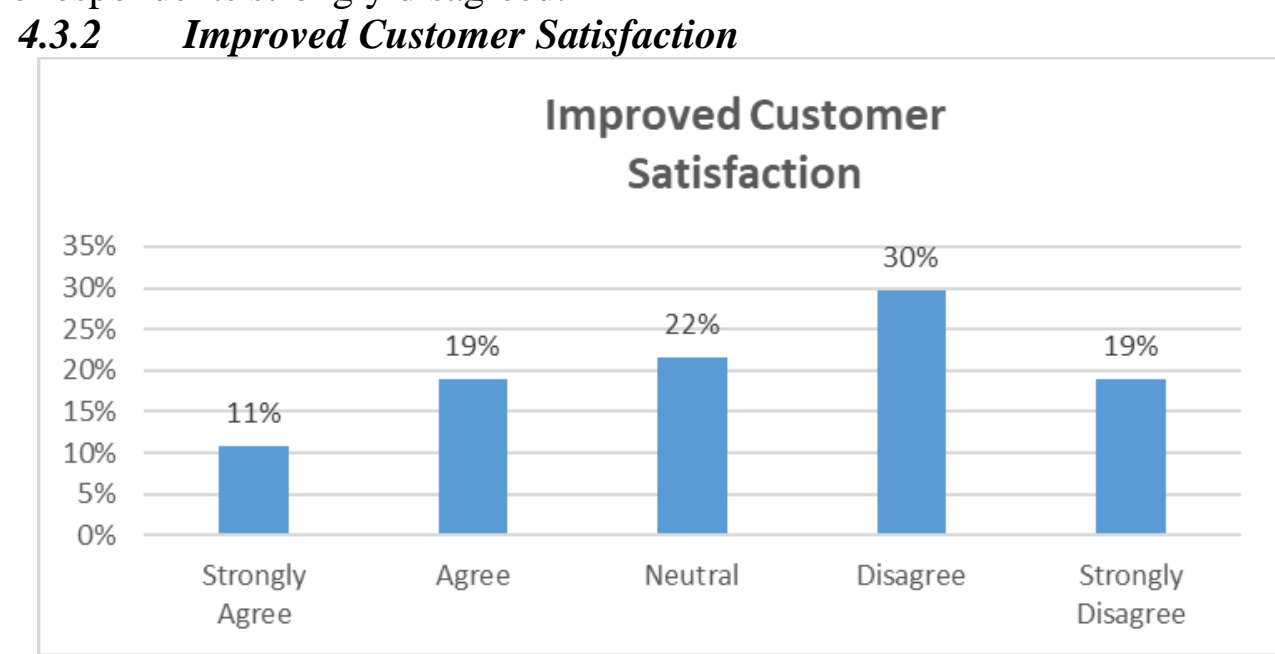

Figure 4.7: Improved Rate of Customer Satisfaction

$30 \%$ of the respondents disagreed that agile supply chains improved the rate of satisfaction of automotive customers. 19\% strongly disagreed, while 19\% agreed. $11 \%$ percent of the respondents agreed, while $22 \%$ neither agreed nor disagreed. Overall, $39 \%$ of the respondents did not feel that agility is responsible for improved satisfaction rates among customers.

\subsubsection{Increased Flexibility}

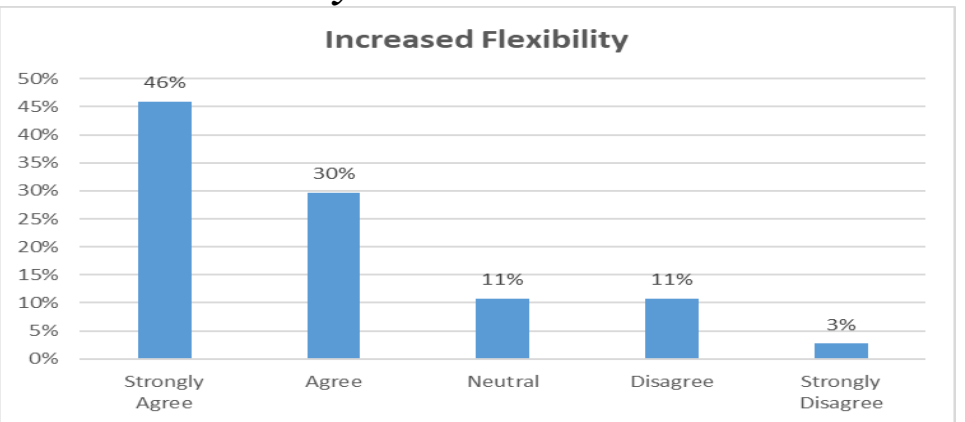

Figure 4.8: Response on Increased Flexibility

$46 \%$ of respondents strongly agreed that agile supply chains improved flexibility in the distribution networks of automotive dealers while $3 \%$ strongly disagreed. $30 \%$ agreed while $11 \%$ disagreed. $11 \%$ remained neutral. $76 \%$ of the respondents confirmed that agile supply chains increase the level of flexibility, while $14 \%$ did not think agility improved flexibility in the distribution networks of automotive dealers. 


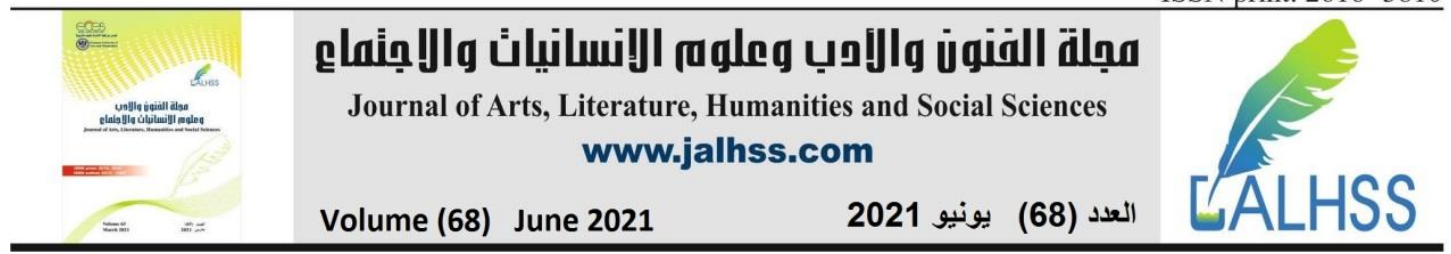

\subsubsection{Reduced Operational Costs}

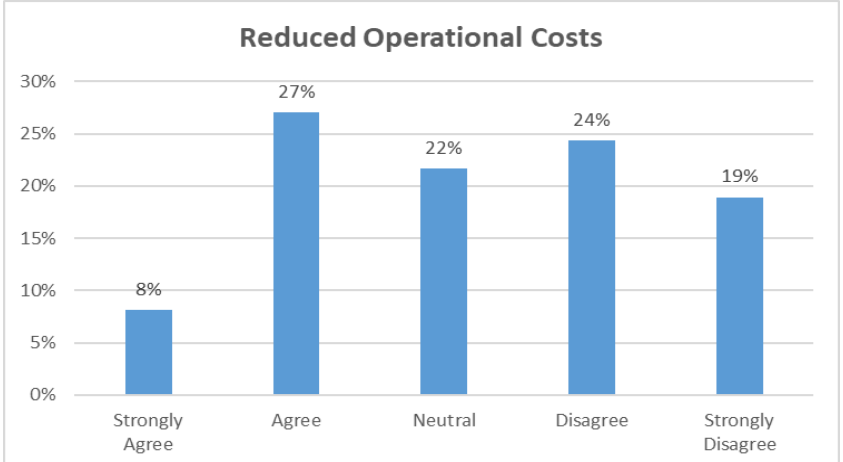

Figure 4.9: Response on Reduced Operational Costs

$24 \%$ of respondents disagreed that agile supply chains reduce overall operating costs in the distribution networks of automotive dealers. $19 \%$ strongly disagreed while $27 \%$ agreed. $8 \%$ strongly agreed while $22 \%$ remained neutral. Overall, $43 \%$ respondents rejected the statement while $35 \%$ accepted the statement.

\section{Discussion}

Agility has indeed emerged as one of the dominant forces that control competition in the automotive industry. Literature confirm that firms that adopt agile techniques report a greater level of competitive advantage in terms of customer acquisition and retention than those that do not employ agile techniques. This is especially important for companies that are operating in ever-changing business environments (Tseng \& Lin, 2011). Companies that adopt agile supply chains tend to benefit from various operational aspects of these chains. However, the benefits associated with agile supply chain models are more presented in theoretical forms than in practical variants. This form of presentation is a source of doubt to analysts and industry executives who are still not yet sure about the specific impacts they would experience if they implement agile techniques in the supply chain of their distribution networks. Such executives want practical evidence and not theoretical explanations and assumptions to convince them that agility in supply chain works for the benefit of their companies. This research targeted the practical perspective of these benefits by looking at the impact of agility using real-life experience from individuals that implement and oversee successes of agile processes in their organizations.

\subsection{Agility and Speed of Distribution Networks}

A considerable percentage of existing literature on agility and lean manufacturing depict agility as a tool that precipitates the speed at which companies deliver their services to customers. This research study confirms these depictions in the context of the automotive industry in Saudi Arabia. A hypothesis analysis using the Chi-Square test for ordinal data confirm that agility increases the speed at which automotive dealers deliver products and additional services to their customers. Further analysis using the frequency tests reveals that $76 \%$ of people in the Saudi Arabian 


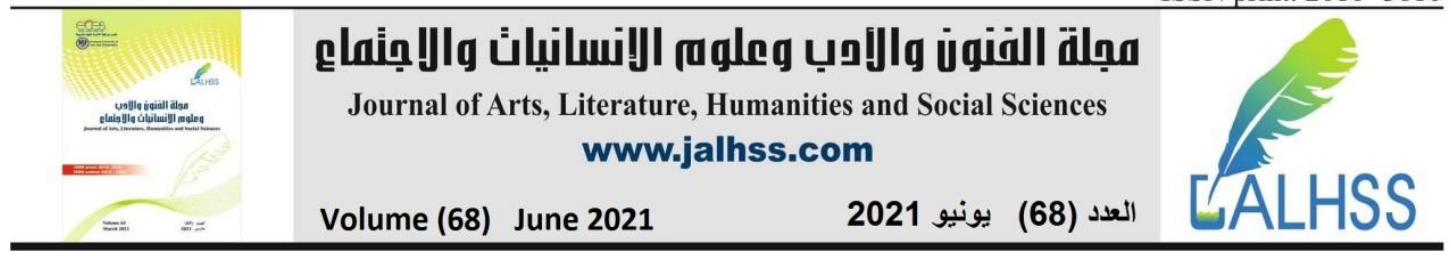

automotive market attest increased speed of service delivery to agile techniques in their supply chain strategies.

The findings from this research show a close correlation with the existing literature on the relationship between agile techniques and speed of service and product delivery. According to Khastoo and Raad (2017), speed is one of the key characteristic features that define agile techniques. However, speed in agile supply chains is a composite of decision making. Quick decision-making capabilities and the ability to change in the speed of orientation direction is fundamental necessity for successful agile supply chains. Even though decision making was not investigated in this research, the findings give strong evidence that confirms agility as a tool needed to increase the speed of service delivery among automotive dealers in Saudi Arabia.

\subsection{Agility and Customer Satisfaction}

The research findings did not give strong evidence linking supply chain agility to the level of customer satisfaction in the automotive dealership industry. This discovery means that the linkage between agile techniques and level of customer satisfaction continues to be a subject of debate. A majority of respondents did not agree with the statement that agility increases the level of satisfaction of customers among automotive dealers in Saudi Arabia. However, the variance between the people who agreed with the statement and those who did not disagree was only $9 \%$, with those agreeing being 30\% and those disagreeing at 39\%. These statistics mean that even though a larger percentage of people believe agility does not contribute to customer satisfaction, a considerable number think otherwise. This group of people who believe that agility contributes to customer satisfaction may have been those who responded in the affirmative on speed and flexibility. This means that there tends to be a direct correlation between speed, flexibility, and the rate of customer satisfaction in this research. Ambe (2009) confirms this correlation in a study conducted to determine the impacts of agility. He states that agility tends to reduce the time it takes for ordered products to reach the targeted customers, which in turn reduces delays, increasing their level of satisfaction in the process.

\subsection{Agility and Flexibility}

Another fundamental variable that was considered in the research is flexibility. The study found a close correlation between agility and flexibility among automotive dealers in Saudi Arabia. 76\% of the respondents confirmed that agile supply chains increased the level of flexibility of distribution networks in their dealerships. Only $14 \%$ of the respondents disagreed with the statement. As Vickery (1999) mentions, flexibility is a characteristic feature that determines a dealer's capability to make constant adjustments to its distribution networks in order to effectively meet the changing demands of customers and markets. The high confirmation rate in this study is an indication that agile supply chains contribute to a high level of flexibility in supply chain distribution networks.

There was a close correlation between the response rate for speed and flexibility. This is an indication of the huge potential of supply chain networks to not only respond appropriately to the changing customer demands but also do so in a quicker manner. This way, customers will be able to receive personalized and highly 


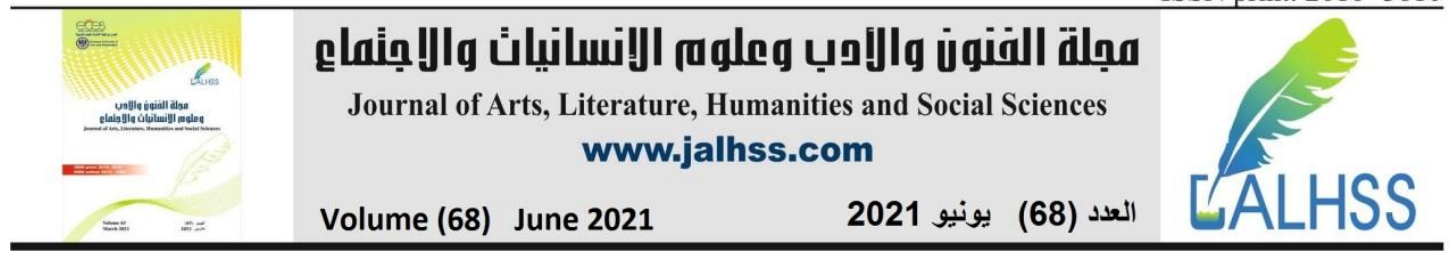

customized services within desirable time limits. Such adjustment has the potential to make Saudi Arabia's automotive market to be one of the most efficient in the Middle East and the world at large.

\section{Conclusion}

This research study confirms the integral role of the agile supply chain of the distribution networks of automotive dealers in Saudi Arabia. Agile supply chains in Saudi Arabia's automotive industry increases the speed at which auto dealers process customers' orders and deliver them. Researchers have found the speed of service delivery as a vital component likely to improve the overall performance of an organization. Apart from the increased speed of service delivery, agile supply chains improve the overall flexibility of Saudi Arabia's automotive dealers. This finding means that auto dealership companies that adopt agility in the supply chain of their distribution networks are highly equipped to respond adequately and satisfactorily to changing customer demands. These demands include changes in feature specifications, consumer behaviour and quantities orders. Effective response to customer demands is a critical differentiation tool in a competitive sector like the automotive markets. There was a considerable degree of relation between respondents who supported flexibility and speed as indicators of the impacts of agile capabilities. This response pattern means that auto dealers who want to improve the speed at which products reach customers while at the same time respond swiftly to the ever-changing customer and market demands must adopt agile techniques in the supply chains of their distribution networks.

However, a majority of auto dealers in Saudi Arabia do not believe that agile supply chains improve the level of customer satisfaction among auto dealerships in Saudi Arabia. While the structure of the research methodology did not allow for an exploratory response, research tends to reject the validity of the response given by respondents in this research. A majority of research publications show a close correlation between agile supply chains and improved customer relations. The reason for the difference between the existing research and this study is due to other factors that are believed to improve customer satisfaction in Saudi Arabia's automotive sector. These factors include product quality, accessibility to products, and the quality of customer experience. It was also found that agile supply chains do not reduce the level of operational costs of auto dealers in Saudi Arabia. Operational costs in the automotive industry are linked to factors that promote lean production models and reduce wastes. However, research links agile supply chains to the lean production models, which means they partly contribute to reduced operational costs among automotive dealers in Saudi Arabia.

Overall, there are strong indications that agility leads to improved supply chains of the distribution networks of automotive dealers. It increases the speed of service delivery and the ability of automotive dealers to respond effectively to changing demands in the market. It is therefore an important tool for ensuring operational efficiency. 


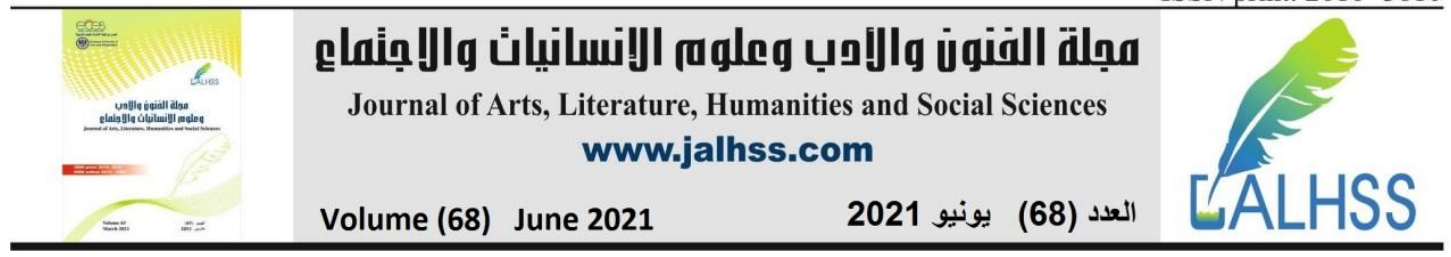

\section{Future Research and Recommendations}

This study used the Likert Scale questionnaires to determine the implications of agility in the supply chain of the distribution networks of Saudi Arabia's automotive dealers. The findings show that agility enhances flexibility and the speed of delivery of services and products among automotive dealers in Saudi Arabia. They also show that agility is not necessarily responsible for an increase in the level of customer satisfaction and reduced operational costs among auto dealers. Future recommendations for this research are to develop a comprehensive research framework that integrates both quantitative and qualitative data to get a wider perspective of the impact of agile supply chains in the automotive sectors of developing countries like Saudi Arabia. Doing so will provide more holistic information and paint an accurate picture of the state of the agile supply chain in the distribution networks of Saudi Arabia's automotive dealers. It will also expand an understanding of the agility concept among workers in the auto dealerships as well as the targeted customers.

The other future research recommendation is to perform detailed empirical studies on the economic, human resource, and technological factors that influence the successful implementation of an agile supply chain in the distribution networks of automotive dealers. This research is vital since it forms the basis of determining the level of success of agile supply chains. Studying and understanding the aspects that influence agile supply chains will enable managers to effectively implement agile concepts and strategies. Effective implementation will, in turn, contribute to the maximization of the positive impacts of agile supply chains, as mentioned in this study.

\section{References}

1. Al-Hashim, M., 2018. An analysis of barriers to supply chain management performance in Saudi Arabia (Doctoral dissertation, Dublin City University).

2. Al-Sadoum, A., 2017. The Role of Technology in Agile Supply Chain Networks, s.l.: OilandGas.

3. Ambe, I.M., 2009, July. Agile supply chain: a strategy for competitive advantage. In The Proceedings Of 5 Th International Strategic Management Conference (p. 659). 4. Aryal, A., Liao, Y., Nattuthurai, P. and Li, B., 2018. The emerging big data analytics and IoT in supply chain management: a systematic review. Supply Chain Management: An International Journal.Heikkilä, J., 2002. From supply to demand chain management: efficiency and customer satisfaction. Journal of operations management, 20(6), pp.747-767.

5. Ambe, I.M., and Badenhorst-Weiss, J.A., 2011. An automotive supply chain model for a demand-driven environment. Journal of Transport and Supply Chain Management, 5(1), pp.1-22.

6. Braese, N., 2005. The dynamics of supply chains in the automotive industry (Doctoral dissertation, Massachusetts Institute of Technology). 


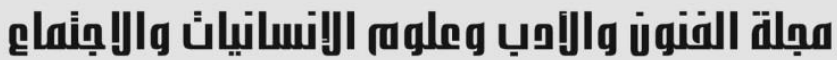 \\ Journal of Arts, Literature, Humanities and Social Sciences www.jalhss.com \\ Volume (68) June 2021 \\ العدد (68) يونيو 2021}

7. Barve, A. 2011. Impact of supply chains agility on customer satisfaction. In 2010 international conference on e-business, management and economics, IPEDR (Vol. 3, pp. 325-329). IACSIT Press Hong Kong.

8. Ben Ruben, R., Prasanth, A.S., Ramesh, R. and Narendran, S.A.P. 2013. Implementation Study on Applying Agile Supply Chain Paradigm in the Manufacturing of a Conventional Automobile Horn in an Indian Company.

9. Carbonero, F., Ernst, E. and Weber, E., 2018. Robots worldwide: The impact of automation on employment and trade. ILO Research Department Working Paper, (36).

10. Chopra, S. (2003). Designing the distribution network in a supply chain. Transportation Research Part E: Logistics and Transportation Review, 39(2), pp.123140.

11. Christopher, M., Harrison, A. and van Hoek, R., 2016. Creating the agile supply chain: issues and challenges. In Developments in logistics and supply chain management (pp. 61-68). Palgrave Macmillan, London

12. Conboy, K. 2009. "Agility from First Principles: Reconstructing the Concept of Agility in Information Systems Development", Information Systems Research, Vol. 20, No. 3, pp. 329-354.

13. Creswell, J.W. 2009. Research Design: Qualitative, Quantitative, and Mixed Methods Approaches, Thousand Oaks: Sage Publications

14. DHL Saudi Arabia, 2015. NEW ENGINE GROWTH FOR AUTOMOTIVE, s.1.: DHL, Inc..

15. Dove R. 1994. "Tools for Analyzing and Constructing Agility", in Proceedings of the Third Annual Agility Forum Conference/Workshop.

16. Gligor, D.M., 2013. The concept of supply chain agility: Conceptualization, antecedents, and the impact on firm performance.

17. Taylor, O. and Demirbas, A., 2016. Forecasting and analysis of energy consumption for transportation in the Kingdom of Saudi Arabia. Energy Sources, Part B: Economics, Planning, and Policy, 11(12), pp.1150-1157.

18. González-Benito, J., Lannelongue, G. and Alfaro-Tanco, J.A., 2019. Study of supply-chain management in the automotive industry: a bibliometric analysis. International Journal of Production Research, 51(13), pp.3849-3863.

19. Grigore, S.D., 2007. Supply chain flexibility. Romanian economic and business review, 2(1), p.66

20. Harrison, A., Christopher, M and van Hoek, R., 1999. "Creating the agile supply chain", working paper, School of Management, Cranfield University

21. Howard, M., Miemczyk, J. \& Graves, A. 2006. Automotive supplier parks: an imperative for build-to-order? Journal of Purchasing and Supply Management. (12):91-104

22. Imran, A. S. \& Rizwan A. S., 2013. Is Supply Chain Management Important To Implement In Manufacturing Industries of Saudi Arabia? 5(27). Pp 58-65

23. Kawa, A. and Maryniak, A., 2019. Lean and agile supply chains of e-commerce: empirical research. Journal of Information and Telecommunication, 3(2), pp.235-247. 


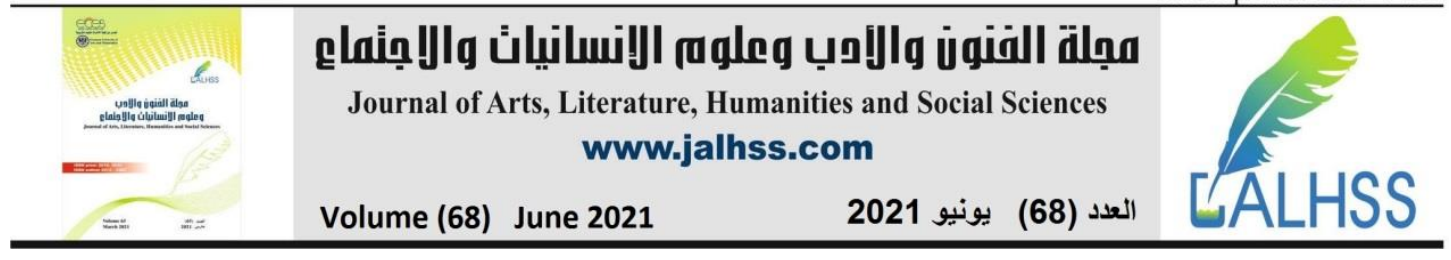

24. Kawulich, B. B. (2005, May). Participant observation as a data collection method. In Forum Qualitative Sozialforschung/Forum: Qualitative Social Research (Vol. 6, No. 2).

25. Khan K, A., Bakkappa, B., Metri, B.A. and Sahay, B.S., 2009. Impact of agile supply chains' delivery practices on firms' performance: cluster analysis and validation. Supply Chain Management: An International Journal, 14(1), pp.41-48. 26. Khastoo, M. \& Raad , A., 2017. Investigate the effect of agility capabilities in the Automotive Industry Supply Chain Network (Case Study: Sapko Parts Auto Supply). International Journal of Environmental \& Science Education, 12(7), pp. 1655-1677. 27. LaLonde, B.J. and Pohlen, T.L., 1996. Issues in supply chain costing. The International Journal of Logistics Management, 7(1), pp.1-12.

28. Mallett, R., Hagen-Zanker, J., Slater, R. and Duvendack, M., 2012. The benefits and challenges of using systematic reviews in international development research. Journal of development effectiveness, 4(3), pp.445-455.

29. Manders, J., 2010. Supply Chain Flexibility aspects and their impact on customer satisfaction (Master's thesis, Open Universiteit Nederland).

30. Mohammad Lou, Akbar. 2016. Developing lean and agile automotive suppliers manufactures supply chain.

31. Mohammadlou, A., Barzamini, S. and Khazir, M., 2016. Developing lean and agile automotive suppliers manufactures supply chain.

32. Navid, B. and Ismaeli, S., 2012. Analyzing effective elements in agile supply chain. Management Science Letters, 2(1), pp.369-378.

33. Power, D.J., Sohal, A.S. and Rahman, S.U., 2001. Critical success factors in agile supply chain management-An empirical study. International journal of physical distribution \& logistics management, 31(4), pp.247-265.

34. Rahman, M.S., 2017. The Advantages and Disadvantages of Using Qualitative and Quantitative Approaches and Methods in Language" Testing and Assessment" Research: A Literature Review. Journal of Education and Learning, 6(1), pp.102-112. 35. Randheer, K., Trabulsi , H., Ajmi, H. \& Jasser, H., 2017. Emerging Industry: A Case of Automobile Manufacturing in Saudi Arabia. Journal of Marketing Research and Case Studies , Volume 2017, pp. 14-17.

36. Saad, M. and Patel, B., 2006. An investigation of supply chain performance measurement in the Indian automotive sector. Benchmarking: An International Journal, 13(1/2), pp.36-53.

37. Saranga, H., Mukherji, A. and Shah, J., 2015. Inventory trends in emerging market supply chains: Evidence from the Indian automotive industry. IIMB Management Review, 27(1), pp.6-18.

38. Saudi Arabia Country Commercial Guide, 2018. Saudi Arabia - Automotive MarketSaudi Arabia - Automotive Market. Saudi Arabia - Automotive Market. Available at: https://www.export.gov/article?id=Saudi-Arabia-Automotive-Market [Accessed July 4, 2019].

39. Tarokh, M.J., Ghahremanloo, H. and Karami, M., 2007, August. Agility in auto dealers SCM. In 2007 IEEE International Conference on Service Operations and Logistics, and Informatics (pp. 1-6). IEEE. 


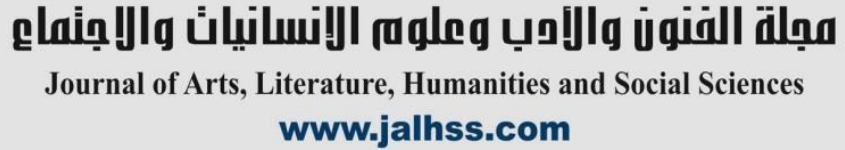

40. Tausif, M. \& Haque, M., 2018. Market dynamics and future prospects of the automobile industry in Saudi Arabia. Problems and Perspectives in Management, 16(4), pp. 245-258.

41. Taylor, O. and Demirbas, A., 2016. Forecasting and analysis of energy consumption for transportation in the Kingdom of Saudi Arabia. Energy Sources, Part B: Economics, Planning, and Policy, 11(12), pp.1150-1157.

42. Towill, D.R. and McCullen, P., 1999. The impact of agile manufacturing on supply chain dynamics. The international journal of Logistics Management, 10(1), pp.83-96.

43. Tseng, Y. and Lin, C. (2011), "Enhancing Enterprise Agility by Deploying Agile Drivers, Capabilities and Providers", Information Sciences, Vol. 81, No. 17, pp. 36933708.

44. Um, J. 2017. The impact of supply chain agility on business performance in a high level customization environment. Operations management research, 10(1-2), 10 19.

45. Vickery, S. N., Calantone, R., \& Dröge, C. 1999. Supply chain flexibility: an empirical study. Journal of supply chain management, 35(2), 16-24.

46. Whitten, G. D., Green Jr, K. W., \& Zelbst, P. J. 2012. Triple-a supply chain performance. International Journal of Operations \& Production Management, 32(1), 28-48. doi:10.1108/01443571211195727

47. Wu, Y. and Angelis, J.J., 2007, May. Information technology and supply chain agility in Chinese automotive industry. In POMS 18th Annual Conference Dallas, Texas, USA May (Vol. 4).

48. Zhang, Q., Vonderembse, M. A. and Lim, J.-S. (2002), "Product development flexibility: testing relationships among competence, capability and customer satisfaction", (Arkansas State University and The University of Toledo). 